\title{
Constructing history on television: Marc Ferro and newsreels in Histoire Parallèle
}

\author{
Sheila Schvarzman[1]
}

\begin{abstract}
In 1989, when Europe was being transformed after the fall of the Berlin Wall and the expansion of satellite communications, $L a$ Sept, a Franco-German TV channel, came into being. Histoire Paralèlle, a TV show hosted by Marc Ferro with newsreels shown in both countries, 50 years before, became the most watched program of the station, comparing the images the ways in which German and French started the war, as it should be seen and experienced by their fellow citizens. The program became a socialized process of understanding and historical rewriting, besides standing before the conflict between memory and history, a question that guided the historiography of the 1990s. This article analyzes Histoire Paralelle, examining the relationship that it established with the historiography and filmic production of the historian. Therefore, its theoretical assumptions are re-discussed and historicized in the context of Ferro's works and through the analysis of three of his programs.
\end{abstract}

Keywords: history; Marc Ferro; newsreels.

\section{Construindo a história na televisão: Marc Ferro e os Cinejornais em Histoire Parallèle}

\section{Resumo}

Em 1989, quando a Europa se transformava com a Queda do Muro de Berlim e a expansão das comunicações via satélite, surge $L a$ Sept, o canal de televisão franco-alemão. Histoire Paralèlle, programa apresentado por Marc Ferro com os cinejornais veiculados nos dois países, 50 anos antes, se torna o programa de maior audiência da emissora, confrontando nas imagens os modos como alemães e franceses construíram a guerra, tal como deveria ser vista e vivida por seus concidadãos. O programa tornou-se um exercício socializado de compreensão e reescritura histórica, além de se colocar diante do conflito entre memória e história, questão que norteou a historiografia dos anos 1990. Este artigo analisa Histoire Paralèlle, observando a relação que estabeleceu com a produção historiográfica e fílmica do historiador. Para tanto, seus pressupostos teóricos são rediscutidos e historicizados à luz das obras de Ferro e por meio da análise de três dos seus programas.

Palavras-chave: Cinema; História; Marc Ferro; cinejornais.

\section{La construcción de la historia en la televisión: Marc Ferro y los cine-noticiarios en Histoire Parallèle}

Resumen

En 1989, cuando la Europa se transformaba con la caída del Muro de Berlín y la expansión de las comunicaciones por satélite surge La Sept, el canal de televisión franco-alemán. Histoire Paralèlle, un programa presentado por Marc Ferro con los cine-noticiarios vehiculados en ambos países, 50 años antes, se convierte en el programa más visto de la emisora, comparando por las imágenes las formas en que alemanes y franceses concibieron la guerra, tal como debería ser vista y vivida por sus conciudadanos. El programa se ha convertido en un ejercicio socializado de comprensión y reescritura histórica, además de estar delante del conflicto entre la memoria y la historia, una cuestión que guio la historiografía de la década de 1990. Este artículo analiza Histoire paralelle, observando la relación que se establece con la producción historiográfica y fílmica del historiador. Por lo tanto, sus supuestos teóricos se rediscuten y contextualizan a la luz de las obras de Ferro y mediante el análisis de tres de sus programas.

Palabras clave: Cine; Historia; Marc Ferro; cine-noticiarios.

\section{La construction de l'histoire à la télévision: Marc Ferro et les actualités en Histoire Parallèle}

Résumé

En 1989, lorsque l'Europe se transformait avec la chute du mur de Berlin et l'expansion des communications par satellite, se pose La Sept, la chaîne de télévision franco-allemande. Histoire Paralèlle, présenté par Marc Ferro avec actualités servi dans les deux pays, 50 ans avant, devient le programme le plus regardé de la station, en confrontant les façons dont les Allemands et les Français ont construit la guerre, comme elle doit être considérée et vécue par leurs concitoyens. Le programme est devenu un processus socialisé de compréhension et de réécriture historique, et sest placé avant le conflit entre mémoire et histoire, question qui a guidé l'historiographie des années 1990. Cet article analyse Histoire Paralèlle en regardant la relation établie avec l'historien de production historiographie et de films du historien. Pour cela, les hypothèses sont discutées et historicisées à la lumière de ses œuvres et à travers lanalyse de trois de ses programmes. Mots clés: Cinéma; Histoire; Marc Ferro; actualités. 
$\mathrm{E}$ xamining the filmic files about World War I, in 1964, Marc Ferro realized that pictures conveyed different information, known by written documents. After this finding, which was based on the observation of the German population's joy with 1918 truce, when rendering terms were still unknown, the historian could understand the disillusion and furor that followed the idea forged by the German army. This idea was that the country had not lost the war; however, its adversaries had cheated it, a rationale that fed the infatuated reactions of the disturbed period between wars. Soon after, Ferro analyzed the Russian movies from the beginning of the 1920s, with new situations about living in Russia that did not correspond to what was known as bibliography. From this point on, the first theoretical reflections about the possibility of the cinema as a historian's source arouse at the same time when it started to be part of Annales.

Even though nothing prevented the study of films by historians, since Seignobos and Langlois ${ }^{1}$ in 1898 recognized that literary or theatrical works allow us to know periods of rare documentation, there were few investigators who saw the filmic files or even fiction films until the 1960s. ${ }^{2}$ Also, few were those who opened and directed themselves toward the cinema as a source to study History, with the developments we can see today - already spared from many constraints because in the 1970s, marked by Marxism in their historical studies, cinema was not seen as a reliable study document.

Therefore, it was necessary to legitimize the study of cinema by historians. However, accepted or not, Ferro kept researching contemporaneous history, producing and analyzing movies ${ }^{3}$ - with his observations about the pictures being incorporated to the historical knowledge he produced. From these studies, he deepened his historiographical knowledge, marked by the comparative bias of which the research with pictures was one of the trigger poles, since instead of considering that the pictures made errors when their content was different of that was already known by historiography, he created doubts on the explanations that were already established.

Among the several works of cinematographic analysis and performance that he created, Histoire Paralèlle, a television show that was shown from 1989 to 2001 at La Sept channel, became very significant due to the historian's intervention in the media space. The program, which was based on the comparative exhibition of newsreels from warring nations involved in the World War II, allowed - and remained, due to the good response of the

\footnotetext{
'Charles Seignobos; Charles Victor Langlois, Introduction aux Etudes Historiques, Paris, Librairie Hachette, 1898. 2Sigfried Kracauer, De Caligari a Hitler. Rio de Janeiro, Jorge Zahar, 1988 [1947]; Edgard Morin, O cinema e o homem imaginário, Lisboa, Relógio d'Água, 1997 [1956] - two authors that are not historians. Robert Mandrou, in "Histoire et Cinéma", Annales E.S.C, vol. I3, n. I, Paris. 1958, p. 140, proposes a social history through the visit to movie theaters. In the United States, the focus appears mainly in the 1970s, in the classic adaptation MovieMade America: a cultural history of American movies, New York, Ramdon House, 1975, by Robert Sklar, or in the magazine Film \& History, from 1971.

IIn the 1970s, he directed Images de l'Histoire, 13 movies of 13 minutes for Hachette - Pathé Cinéma with titles like Lénine par Lénine (1970), among others. Institut Nacional de l'Audiovisuel (INA). Lénine par Lénine. Available from: <http://www.ina.fr/histoire-et-conflits/revolutions-et-coups-d-etat/video/CPF86624225/leninepar-lenine.fr.html>. Accessed on: March 6, 2014.
} 
audience - , a public and continuous historiographical exercise by revising the recent past of both countries. At the same time when the Berlin Wall fell and Europe started its resettlement, in which Pierre Nora used memory, its places, and celebrations as the center of historiographical debates, the new French-German channel promoted a joint historical-memory review of the last great conflict to make their populations opposed. The newsreels seen or re-seen by the audience became, in this operation, documents that were accessible and shared in an extensive and significant diffusion together with an average audience of around 1.2 million viewers, ${ }^{4}$ which makes Histoire Parallèle the show with the highest viewers of the channel.

In May 1989, La Sept, which was the French-German cultural television channel presided by the historian George Duby, began working. The start of such channel as the "European Society of Television Programs" marked the friendship bounds that should unite both countries that had been enemies for ages. On September 1, Marc Ferro and the German historian Klaus Wenger started hosting Histoire Parallèle, showing the newsreels broadcasted in the cinemas of the two countries 50 years ago when they were getting ready for the war.

The full broadcasting of both newsreels enabled the dialogue, triggered memory, and caused emotions and surprise. It led to a reflection on the construction of known historical narratives: each country's emphasis on common facts, how they were organized, their thematic linking, cinematographic rhetoric that they nurtured (filmic construction, the off voice, ${ }^{5}$ and musical background). The war was seen, re-seen and, by many, re-lived, causing some reactions. The broadcast, which was projected to happening only for some months, was extended for 12 years, when it monopolized all belligerent countries that collaborated for filmic material sending, besides historians, specialists or witnesses that came from Italy, Japan, the United States, England, and Soviet Union to take part in the discussions on the program. After the transmission of war movies ended, the program remained in air and focusing decolonization, European Union formation, among other subjects, until 2001 when it ended, due to the shortage of newsreels pictures in the files, according to Ferro. ${ }^{6}$

However, it is not arbitrary to conclude that a program that would revisit the European history from newsreels started being produced at the same time when the continent was in strong political ebullition, which culminated in the collapse of communism in Eastern Europe countries. Histoire Parallèle is part of this new historical inscription of Europe. Nevertheless, it is also a result of Ferro's historiographical work, in which the contemporaneous history could not be disassociated from the image and audiovisual means of its production

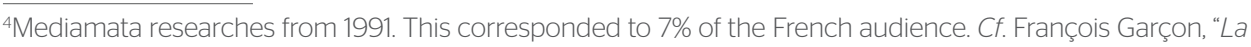
réussite d'Histoire parallèle", Cinemaction, n. 65, Paris, 1992, p. 60.

${ }^{5} \mathrm{Cinematographic} \mathrm{term} \mathrm{that} \mathrm{means} \mathrm{the} \mathrm{narrative} \mathrm{performed} \mathrm{by} \mathrm{somebody} \mathrm{who} \mathrm{is} \mathrm{not} \mathrm{in} \mathrm{front} \mathrm{of} \mathrm{the} \mathrm{cameras.}$ 'Laurent Veray, "De la BDIC à Histoire parallèle - regard d'historiens et de témoins sur les Archives", Materiaux pour I'histoire de notre temps, n. 89-90, Paris, 2008/1-2, p. 147-155. Available from: <http://www.cairn.info/article. php?ID_ARTICLE=MATE_089_0025>. Accessed on: March 5, 2012. 
and reception. The newsreels, an essential communication element during the war on the face of regimen, especially in Goebbels' Germany, became before everybody, through television, a historical document for new studies. As it is seen in a wide and critical manner, it is rescued and thus widely given a different meaning that enables new reflections.

Furthermore, virtues and limitations of the program, as we will point out, testify the manner of treatment given to the cinema by the historian, a treatment that has been absorbed for a long time, criticized in its limitations, and enriched by several historians in the entire world, including Brazil. ${ }^{7}$

$$
\begin{aligned}
& \text { There were few who saw } \\
& \text { the filmic files or even fiction } \\
& \text { films until the } 1960 \text { s }
\end{aligned}
$$

Thus, in this article, we have tried to understand how Marc Ferro tried to do his path, since his first studies using movies from 1964 until Histoire Paralèlle. This is a work of more than 40 years of reflections, re-visitations, and contextualization of the imbrication between works with movies — analysis and performance - and his historiographical contributions, in order to understand how they culminated in the TV show that he hosted and, from this point, analyze three TV shows.

\footnotetext{
It is a little difficult to summarize the many lines in which these studies and their repercussions were unfolded, which, since the 1970s in the United States and in France (to mention only these) and from the 1990s in Brazil, deepen and criticize Marc Ferro's reflections, especially the centrality given to the Cinema study as a source for the historian or his idea of counter-history. Works like Robert Rosenstone, A história nos filmes - os filmes na história, São Paulo, Paz e Terra, 2010, or William Guynn, Writing History in film, New York, Routledge, 2006, widen and update these premises from the most profound and close relations with Cinema History and filmic analysis. This is a focus that Michele Lagny is very interested in texts like História e Cinema, In: René Gardies, Compreender o cinema e as imagens, Lisboa, Edições Texto \& Grafia, 2006, or Antoine de Baecque, in L'Históire-Camera, Paris, Gallimard, 2006, or even the Israeli Shlomo Sand in Le XXe siècle à l'écran, Paris, Seuil, 2002. Thus, the borders of what was understood as Cinema history were extended with investigations done by François Garçon in De Blum a Petain, Paris, Le Cerf, 1984, or by Jean Pierre Bertin Maghit about the French cinema during the German occupation, propaganda movies, in Les documenteurs des années noires, Paris, Nouveau Monde, 2004. In Brazil, Alcides Ramos, in O canibalismo dos fracos, Bauru, Universidade do Sagrado Coração, 2001, discusses in details the associations that were established between Os Inconfidentes, a 1972 film by Joaquim Pedro de Andrade, and the Brazilian military dictatorship. Meanwhile Sheila Schvarzman, in Humberto Mauro e as imagens do Brasil, São Paulo, Editora da UNESP, 2004, through the movie maker's work, talks about the construction of images about Brazil in Vargas period between many and many other papers to mention inside and outside Brazil. Since focus is the representation, reconstruction, or influence on History, filmic files and their use cannot be out of it. Sylvie Lindperg, referring only to her last book, La voie des images, Paris, Verdier, 2013, or the Spanish Vicente Sanchez Biósca, with NO-DO: el tiempo y la memoria, Madrid, Cátedra, 2005, or even Jaimie Baron, in "The Archive Effect", Projections, vol. 6, n. 2, 2012, provide us with significant examples. Besides, making the historian close to Cinema studies has been changing his historiography, as seen in reflections like Film history: theory and practice, by Douglas Gomery and Robert Allen, New York, Knopf, 1985, or Michele Lagny, De I'histoire du Cinéma: méthodes historiques et Histoire, Paris, Armand Colin, 1992, among many others.
} 


\section{Marc Ferro: History, Historiography, and Cinema ${ }^{8}$}

When documentaries of historical themes that make use of file images are seen, there is a discord between the locution text and images. Pictures seem to have been chosen as a locution of an idea that came before the images. A few times, even due to the difficulty with documents, information is strictly visual and presented without a text. In 1918: le dénouement (the outcome), ${ }^{9}$ produced in 1968 by Ferro on the occasion of the 50th anniversary of the World War I armistice, we observed pictures of the soldiers' comeback to France, England, the United States, and Germany. If in the pictures of the first three countries, the reception is more friendly, in the loser country, it is not dismal as expected by what it is known through bibliography, which surprised the historian as previously mentioned. Using a superposition of these different pictures obtained in the newsreels, Ferro developed a historiographical discussion: he wrote through images, found different pieces of information from that known by the established historiography, called attention to its possibilities of analysis and assumption by the historian.

\section{Is it a dated relation?}

The relation between History and Cinema, as developed by Marc Ferro in the beginning of the 1970s, was determined through the nature of phenomena that he analyzed, such as the Russian Revolution or Stalinism. These events are marked by the political dispute of the historiographical construction and supervision of the documentation. Movies gave him the opportunity of accessing the information that was then difficult to obtain through other sources.

As he was becoming more experienced with soviet files, he observed that the artistic and fictional characters of cinema made it difficult for institutions to control his content. They made the control by bureaucrats that are used to seeing the real danger in the sound, instead of in the image, more difficult. Political control occurred on the words, on what the characters used to say, while moral censure cut what the movies showed. ${ }^{10}$ The nature of the cinema showed that lapses were evident. If there was censure, there was also a content escaping it. In addition, cinema, based on images, allowed seeing the fragments that were not said

\footnotetext{
${ }^{8}$ resume and update herein considerations of the chapter "Cinema, História e Marc Ferro", from my Master's degree dissertation Como o Cinema escreve a História: a América e Elia Kazan, Universidade Estadual de Campinas, Campinas, 1994.

9INA. 1918: le dénouement. Available from: <http://www.ina.fr/histoire-et-conflits/autres-conflits/video/ CPF86606060/1918-le-denouement.fr.html>. Accessed on: March 5, 2014.

${ }^{10}$ Marc Ferro, La Révolution Russe de 1917, 2. ed., Paris, Flammarion, 1977, p. 18-39.
} 
to emerge, despite the controls. The historian had access to a new and different documentation from that found in files controlled by the State or Communist Party when he analyzed such fragments. ${ }^{11}$

In this 1970s historiographical formulation, it is possible to see the influence of psychoanalysis, often used as an interpretational instrumental of cinema, ${ }^{12}$ and also the prevalence of the ideology prevalent in the same decade with its hidden contents, so the historian was in charge of unraveling them, returning them to historical knowledge. However, as we will show, in the analysis performed by Ferro in Histoire Parallèle, it is not only a lapse - as he said in his first texts -, but as seen in the newsreels analysis from 1989 of distinct and new contents that were produced in the image - given to the historian to realize and authenticate. We will further discuss more examples.

In 1964, as the consultant of a documentary about World War I, contact with newsreels made him notice that "images do not produce the same past representations of written files" ${ }^{13}$ From the study of soviet movies, cinema started to be used as a source of another history; therefore, it was possible to make criticism about knowledge from written documents. La Rèvolution Russe de 1917: Octobre, naissance d'une societév provides some examples of the scope of such procedure, because it uses observations of movies as a documentation, with the same statute attributed to traditional sources. This allows "legitimizing the image as a historical source compared to the already known sources". ${ }^{4}$

\section{Cinema and History: a chronicle}

Today, almost 50 years after the appearance of studies about Cinema and History, it is possible to analyze the historicity of how and why movies began to be an interest of historians in France: "Historicity forces inserting history in a historical perspective. There is a historical historicity that causes movement that links an interpretational practice to a social practice". ${ }^{15}$ Thus, after observing the movie historicity as a study aim and source for the historian, we must rethink it in light of its own genesis, where ideas of the New History, their contributions, cultural and social reality after 1968 post-May, and the cinema of that time are mixed.

\footnotetext{
"A part of Marc Ferro's argumentation in Analyse de film, analyse de sociétés: une source nouvelle pour l'Histoire, Hachette, Paris, 1974, and in Cinema e História, São Paulo, Paz e Terra, 2010, a book that is a collection of articles from the 1970 s that were based on this idea.

${ }^{12}$ Check Cristian Metz' influence and his seminar in the same École, besides his publications, like Essais sur la signification au Cinema, Paris, Klincksieck, 1968, or Langage et Cinéma, Paris, Ça Cinéma, 1971. ${ }^{13}$ Alain Besançon et al. "L'expérience de la 'Grande Guerre'”, Annales E.S.C., n. 2, 1965, p. 327-336.

${ }^{14}$ François Garçon; Pierre Sorlin, "De Braudel à Histoire parallèle ", Cinemáction, n. 65, Paris, 1992, p. 53.

15Jacques Le Goff, Enciclopédia Einaudi, Lisboa, Eunaudi, 1984, p. 159.
} 


\section{"A bourgeois machine"}

In the 1970s, in magazines, like Cahiers du Cinéma, cinema was considered a "bourgeois machine", "a place of dominant ideology production and therefore oppression". ${ }^{16}$

In 1980, Jean-Claude Bernardet, in O que é cinema, explains these ideas:

The cinematographic machine does not fall from the sky [...] In the most important dominator euphoria, bourgeois develops a thousand and one machines and techniques that will not only make its domination process and the capital accumulation easier, but they will also create a cultural universe to its image. ${ }^{17}$

Without holding on to the quality of these statements, they were the criticisms of how cinema was seen at that time. Essays of Cahiers du Cinéma or disciples of Christian Metz, among others, sought upon semiology and linguistics, paths for the creation of criticism cinema, instead of a bourgeois one. In order to do so, Cahiers from the 1970s refers to Russian filmmakers such as Dziga Vertov and Sergei Eisenstein, besides reflections about the cinematographic technique - seen as bourgeois, because they reproduced the renaissance's perspective and "natural" idea, and that is why the "real" of what it is seen. "Technique and ideology" (n. 231), "The technique fetishism" (n. 233), and "Ideological policy and fight of social classes" (n. 234) tried to be opposed to this hegemonic view. In 1974, cinema directed to anti-imperialist fights was a dominant theme: cinematography from Brazil, Chile, and Algeria was discussed and in the Antiretro series, cinema history rewriting mainly questioned the German occupation in France. This began to be done especially with Lacombe Lucien (1974), by Louis Malle, in which "pétainism and collaborationism ghosts were treated", according to columnists, in a "bourgeois manner".18

With the aim of having a point of view about these issues, the magazine interviewed Michel Foucault, "whose systematic work is to replace what the official text represses, what is being agitated hidden in the damn files of the dominant class". ${ }^{19}$ Foucault shows that control over popular memory was at risk in that moment, which had been happening since the 19th century through reading and basic schooling. Upon this control,

the historical knowledge that the working class has on itself does not stop decreasing [...] Now, cheap literature is not enough anymore. There are much more effective ways, i.e. television and cinema. I also believe that (control for teaching, TV and cinema) was a way of re-codifying popular memory that exists but does not have a mean to be formulated. Then, people are shown with not what they were, but what they should remember they were. ${ }^{20}$

\footnotetext{
${ }^{16}$ Cahiers du Cinéma, n. 218, Paris, Éditions de l’Étoile, 1970, p. 3-4.

${ }^{17}$ Jean-Claude Bernardet, O que é Cinema, São Paulo, Brasiliense, 1980, p. 15.

${ }^{18}$ Pascal Bonitzer; Serge Toubiana, Cahiers du Cinéma, n. 25I-252, 1974, p. 4

${ }^{19}$ Michel Foucault, "Anti-Retrô”, Cahiers du Cinéma, n. 25I-252, 1974, p. 5.

20/bidem, p. 7
} 
The magazine tried to dismantle the cinematographic language mechanisms so that its working is clear and it could be reverted into a "conscious and engaged" cinema, having power over "reality effect" of the image for the fair cause.

\section{The "Cinema and History" seminar}

Amid these questionings and considering the historian as somebody that returns history to society, as Ferro, there was the development since the beginning of the 1970s of the seminar "Cinema and History" at the École des Hautes Études en Sciences Sociales.

The soviet cinema, Nazi documentaries and movies, and Vichy ${ }^{21}$ or Elia Kazan cinemas are some of the themes in which historical and filmic constructions were studied.

\section{Using a superposition of these different pictures obtained in the newsreels, Ferro developed a historiographical rationale}

While cinema was being re-analyzed regarding technique, themes, and political involvement, there was a debate in light of the constructions of views of History, of new information and versions, in the seminar. Therefore, not only how the movie was involved - a "historical agent" 22 - but also how it historically happened in and out of the movie was analyzed: from the ideological involvement to historical criticism. Cinema was not supposed to become an ideological weapon, like the magazine used to state, but it tried to understand how this happened and understand it as a "counter-analysis", a vehicle of new historical construction and mainly dissonance. ${ }^{23}$

Study of the associations between Cinema and History, as seen, is a worry inserted in its time, with date and place. A significant part of Ferro's texts about such theme was written in that period; therefore, it carries a lot of this, revealing emphasis that was a long time ago surpassed by bibliography and its posterior texts.

In 1975, unraveling issues were in agreement with the theme of the historian's researches, due to the phenomena that he had studied and movies that he had seen: Stalinism, Nazism, Vichy movies - they were all products of the tension between what could be done and what could be shown. Before this filmic

\footnotetext{
${ }^{21}$ Vichy's cinema points movies produced by French with the support of German authorities in the area occupied by Germans in France during World War II.

${ }^{22}$ Another denomination used in his books.

${ }^{23}$ Marc Ferro, "O filme: uma contra-análise da sociedade?", In: Jacques Le Goff; Pierre Nora (Orgs.), História: novos objetos, Rio de Janeiro, Francisco Alves, 1976, p. 199-215.
} 
universe, in which movies try to pass political messages and take possession of History, it is possible to understand the role of the ideology in this conceptual universe to understand cinema.

Then, in 1985, in The Watched History, ${ }^{24}$ emphasis was given to appropriation and control over History work. It deals with "focuses" and their possibilities in the construction of pluralist views, varying from silences and parties to popular memory and cinema. The multiple focuses occur after duality. The idea of control over History, of its abuses, takes the place of ideology and unraveling.

When Ferro considered cinema as the "focus" of views about History, he was worried about the kind of construction that the moviemaker was able to produce. "When it is possible to perform an autonomous analysis, he declares his own world vision, regardless of the ideologies and power institutions". These movies contribute to the ability of putting History under issue and not only valuing it by staging.

Révoltes, révolutions, cinéma, from 1989, a year that is remembered by its celebrations of the Bicentennial Anniversary of the French Revolution, summarizes the rebellions and revolutions shown in the cinema. Ferro discusses about the historicity of rebellion and revolution concepts since 1830 until the Chinese Revolution and observes how throughout History the cinema has applied them. In the French Revolution, at the post-war works, he declares "that French movies are never totally favorable [...] The revolution in the cinema has the role of the catastrophe that happens in characters' lives, which interferes in his personal life...." ${ }^{26}$ There is no interest anymore to the meaning of the movies and their value as a source, but on how they built History:

The theme of a movie has less importance than its treatment. Moviemakers that deal with a revolutionary phenomenon try to value it, instead of putting it under question. But moviemakers' revolutionary action happens in another way. ${ }^{27}$

Thus, the issue is "finding through imagination a real path to understand History and make it intelligible".28

Between 1976 and 1981, Ferro did with Jean-Paul Aron the TV show Une Histoire de La Médicine ${ }^{29}$ including eight documentaries about epidemics, body opening, and story of diseases. It was a docudrama ${ }^{30}$ with fictional scenes that re-established important issues, such as the moment when

\footnotetext{
${ }^{24}$ Marc Ferro, A História vigiada, São Paulo, Martins Fontes, 1988 [1985].

${ }^{25}$ François Garçon; Pierre Sorlin, "De Braudel à Histoire parallèle”, Cinemáction, n. 65, Paris, 1992, p. 172

${ }^{26}$ Marc Ferro (Org.), Révoltes, révolutions, cinéma, Paris, Éditions Centre Pompidou, 1989, p. 32-33.

${ }^{27}$ Ibidem, p. 34.

${ }^{28}$ /bidem, p. 35

${ }^{29}$ INA. Marc Ferro: images de l'Histoire. Available from: <http://www.ina.fr/recherche/search?search=Images+de + +\%C2\%B4Histoire+-+Marc+Ferro+\&vue=Video\&x=12\&y=12>. Accessed on: December 2, 2014.

${ }^{30}$ Docudrama or docu-fiction is a documentary with act of fact reconstitution.
} 
diseased were isolated or the creation of a hospital. ${ }^{31}$ The historian enters into a new field, framing his questions from Medicine interventions over the body. Ferro would also be in charge of the script of Pétain, by Jean Marboef (1993), among others.

During that period, his works included studies on Russia and former Soviet Union, as well as other Arabian countries, especially the former French colonies, French history, and finally, the constant reflection about history writing. All these aspects, however, were never disassociated from the audiovisual study and its role in the development of these histories. Discussing Histoire Paralèlle put into perspective these several questions and provided new findings about the history of World War II, among others. ${ }^{32}$

\section{"Parallel History"}

\section{Historians in the media}

The presence of new historians such as Jacques Le Goff, Pierre Nora, and Emanuel Le Roy Ladurie in the media has been known since the 1970s. Since the 1960s, due to local circumstances of larger access to university, there was a demand for historical productions. Not only books or novels of vulgarization, but also other works were produced by experts. This made historians from École des Hautes Études and Annales start to direct collections in great publications. According to Rémy Rieffel, these publications were similar to those of legitimation and notoriety, creating "a network of effective selfcelebration" ${ }^{33}$ In 1969, Le Monde des livres, a book review section in Le Monde newspaper, dedicated two pages to the "New paths of historical research", with articles written by Le Goff and Le Roy Ladurie, the latter became a regular collaborator and an intermediator between the newspaper and the university. Many historians start writing in newspapers.

The apogee of this influence became more pronounced in the 1970s. According to market researches, in this period, the French audience began to enjoy reading and listening to radio of historical themes. In a 1977 sounding, $37 \%$ of the audience reported preferring programs with this subject to other (35\%) and sports (23\%) programs. ${ }^{34}$ During 1973-1989, 17\% of the French read history books. According to the author, "the indicators converge: the

\footnotetext{
${ }^{3}$ LLaurent Veray, "De la BDIC à Histoire parallèle - regard d'historiens et de témoins sur les Archives", Materiaux pour I'histoire de notre temps, n. 89-90, Paris, 2008/1-2, p. 147-155. Available from: <http:// www.cairn.info/article.php?ID ARTICLE=MATE 089 0025>. Accessed on: March 5, 2012. INA. Les societés devant l'épidemie: l'impuissance et la peur. Available from: <http://www.ina.fr/economie-etsociete/vie-sociale/video/CPC81050031/les-societes-devant-l-epidemie-l-impuissance-et-la-peur.fr.html> Accessed on: December 3, 2012.

${ }^{32}$ Cinema et Histoire, re-edited in France, in 2003 (in Brazil in 2010), brings these new conclusions. In História da Segunda Guerra Mundial, São Paulo, Atica, 1995, Marc Ferro shows how the audience of the conflicting countries prepared fiction cinema and newsreels for the event.

${ }^{33}$ Rémy Rieffel, "Les historiens, lédition et les medias", In: François Bédarida (Org.), L Histoire et le Métier d'Historien en France, Paris, Maison de la Sciences de l'Homme, 1995, p. 57-73.

34/bidem, p. 66.
} 
historian speech is an answer to the need of an audience eager to lean over their roots and past". ${ }^{35}$ According to Rieffel, this happened due to the quality of books and ability of the authors to communicate with a wide audience. In 1978, there was the launch of "a quality vulgarization magazine" called Histoire, with 80,000 weekly copies, and also the development of collections of pocket books that are written by the same new historians, amongst them Marc Ferro.

However, television shows such as Alain Ducasse raconte and Apostrophes, from 1975, were the ones that weekly commented on book releases, a privileged disclosure (and fame) place for such authors, and it also allowed increase in the number of books.

Even though from 1985 a decrease in interest in History and stagnation in the number of readers was seen, his prestige was still not enough to raise George Duby to the direction of the FrenchGerman La Sept. Ferro's choice for Histoire Parallele as an expert of contemporaneous history with a strong presence in the edition of book and movies and presence at TV and in the media, was not frightening.

\section{The format}

Louisette Neil and André Harris created Histoire Parallèle. At first, Marc Ferro used to comment with the German Klaus Wenger. Later, Ferro was promoted and experts with different nationalities took part in the program, following the scope of countries discussed in newsreels, replacing the German historian. The broadcast follows the calendar from September 1939 in the past and present, highlighting the most significant events every week. The progression of the program depended on the cession of files, of interviewees and experts, and of the relation between images that were seen and the lived present. Histoire Parallèle was telecasted on Saturdays, from 7:30 pm to 8:30 pm with a repeat telecast on Wednesdays at 6 pm. It aired from September 1989 to June 2001, with a total of 630 episodes.

Originally, it should be in only until June 1990 or June 1940, period of the armistice between the defeated France and Germany, which started to occupy a part of the French territory. Since the audience's interest was great, the program remained on air. However, other newsreels were needed, once a "defeated army does not record their defeat". ${ }^{36}$ British files and newsreels produced in Vichy were started to be used.

The 52-minute programs were filled with 40 minutes of newsreels. There were more images than commentaries. Newsreels used to be fully broadcasted in the beginning, but due to their extension, they started to be broadcast interrupted by participants' remarks.

\footnotetext{
${ }^{35}$ Rémy Rieffel, "Les historiens, lédition et les medias", In: François Bédarida (Org.), L 'Histoire et le Métier d'Historien en France, Paris, Maison de la Sciences de l'Homme, 1995, p. 66.

${ }^{36}$ Rémy Rieffel, "Les historiens, lédition et les medias", In: François Bédarida (Org.), L 'Histoire et le Métier d'Historien en France, Paris, Maison de la Sciences de l'Homme, 1995.
} 


\section{Analysis of three programs ${ }^{37}$}

Owing to the multiplicity of the themes, the amount of information, and diversity of experts, in this article, I have chosen to present the first three programs. They have the format that was kept with some alterations and many of the issues that will be discussed later. I will make their description based on their serial format, on the topic of their images, and on the intervention manners of historians, thus allowing observing their functioning, characteristics, limitations, and contribution.

In the text "Criticism about the cinematographic current events, Parallel History, ${ }^{\prime \prime 8}$ Ferro analyzes these and other issues involving the work with filmic files. This means material aid authenticity, filming angles - if the cinematographer is in front of an enemy warlike target, the image was certainly acted - until reaching the content analysis and other necessary procedures for this paper when he declares that: "images provide some kind of information energy that one should master [...]" ${ }^{39}$ However, he does not analyze the nature of newsreel, a serial genre that is in halfway between information, entertainment, and propaganda.

Furthermore, in these broadcasts, experts did not withhold on the cinematographic shapes that gave meaning to the analyzed content (although they may have done in others ${ }^{40}$ ), and "the recorded file is also a file of many ways how to record"," therefore I added this aspect to my analyses. It is not about a filmic analysis, a procedure that is above the possibilities of an article, but of signaling, inside newsreels, devices that create significant visual meanings with strong appeal to fictional forms and genre.

The newsreels as they were called, were created around the 1910s. They are derivations of travelogue ${ }^{42}$ the movie of someone's experience while traveling. This is a derivation, by the way, of presentations of dark cameras and optical equipment originally from the 18th century, which, through drawings and later photography, brought to the spectator visions about the "unknown" world. This, back then, for European countries that produced movies, the countries and cultures that colonized in Africa and in the Orient, was treated as "exotic". ${ }^{43}$ The newsreel, "the world elapse printed in pellicle",44 is a genre that would be developed until the 1970s, and it is the serial derivation of this same look that changes facts in spectacular occurrences and mixes with similar significance, even though hierarchically ordered, politics, fait divers, ${ }^{45}$ fashion and sports, which are its main themes. Propaganda is an important part of its elaboration. Current TV news programs have changed this original configuration very little, adding to them the live news reports, "right now and right here", which increases the gender effects of credibility.

${ }^{37}$ Histoire Parallèle was not edited in DVD due to difficulties with regard to copyrights. In 2010, I had open access to some copies of the shows.

${ }^{38}$ Marc Ferro, Cinema e História, São Paulo, Paz e Terra, 2010, p. 90-109.

39/bidem, p. 98

${ }^{40}$ Jean Luc Godard made remarks about this with Eric Hobsbawn in show 561.

${ }^{4}$ Sylvie Lindeperg, La voie des images, Paris, Verdier, 2013, p. 27.

${ }^{42}$ Fernão Pessoa Ramos, Mas afinal ... o que é mesmo documentário? São Paulo, SENAC, 2008, p. 57.

${ }^{43}$ Laurent Manonni, A grande arte da luz e sombra, São Paulo, SENAC, 2003, p. 57.

${ }^{44}$ Fernão Pessoa Ramos, op cit.

${ }^{45}$ "Diverse facts". It is an expression from the journalistic lingo referring to the pieces of news that were not presented in a section because they have an unused and curious character. 
It is on the effects of credibility that the newsreels used to be based on, on the concept of printed transparent course in the pellicle, in the urgency, and in the manufactured character of immediacy, which not even the expositional documentary used to take advantage. As Fernão Pessoa Ramos reminds, when a documentary is created, it must be, according to John Grierson's original denomination, "the creative interpretation of current events". ${ }^{46}$ In the newsreels, especially on Nazism, there was an interpretation of facts, but what was seen in the image and what the newsreels format authenticated (as still happens with TV news broadcast, for example) was exactly the opposite: only the image of facts.

\section{Broadcast 1: 09/01/1939}

A vignette with pictures about war opens the show: soldiers marching, farewells in train stations, kids leaving, women crying. Hitler speaks and a bomb explodes. The sound with a loud noise provides the images of a serious character. ${ }^{47}$ Marc Ferro starts speaking. His face is in close up against a white background and he declares: "The newsreels that you will see.... He presents the circumstances of the moment before the start of the war, when negotiations between the English and French did not have a result on the Germans, and describes the non-warmonger atmosphere prevailing in France. Wenger presents the German scenario. There is emotion in the air and Ferro speaks about his memories about the period. Then, the newsreel of Pathé producer is broadcasted. Ferro talks how the movie is constructed in an atmosphere that is still pacific between the French, even though the surprise attack on Poland had imposed mobilization before the perspective of the conflict. He points out how the linking of actions developed by the newsreels referred to forms and occurrences of the World War I: preparation of barricades, children sent to the countryside, distribution of gas masks, among others. The focus is on rearguard and defense. In the German pictures, differently, Franz Wenger reports how they show the preparation of war and criticize English and French enemies by intransigence in the negotiations, a reason that makes them, in the Nazi view, in charge of the conflict emergence. A new vignette ends the show with pictures of Reichstag explosion, among others.

\section{Broadcast 2: 09/07/1939}

The format and vignettes that remained until the last broadcast in 2001 are present. Ferro presents the circumstances of the week: as a reaction to the invasion of Poland, England and France declare war against Germany on day 3. Why the delay? The countries had given Germany an ultimatum to get out of the Polish territory, which did not happen. Besides, the French forces were smaller than the Germans: "Germans are four times stronger than us and we know this, something that will not be said in the newsreel", the historian reports.

Pathénewsreel starts with the word "WAR" and describes how much France has been fighting for peace, with pictures of the Parliament and of the allied ministries in useless negotiations before Germany intransigency. There are pictures of crowds

${ }^{46}$ Fernão Pessoa Ramos, Mas afinal ... o que é mesmo documentário? São Paulo, SENAC, 2008, p. 56.

${ }^{47}$ La 7 histoire parallele juillet 1990. Available from: <http://www.youtube.com/watch?v=06Ss9ydsFSk> Accessed on: March 6, 2014 
on streets buying newspapers. Summon of members of the military forces in France, England, and Holland exposes a crowd of men at train stations. The music signals gravity and urgency. Men wearing military uniforms kiss their sons that are on their wives' laps, crying. From the window of the train, there are gestures from soldiers that are leaving. In the cities, precautions are taken against air attacks. Children receive gas masks. In the Parliament, there is a voting for resources to enter in the war. The archbishop from Paris prays for peace around a crowd of believers. Some scenes of Franklin Roosevelt's office, who requested the removal of Germans from Poland: "All Polish people respond to the aggressor", the locution says. Scenes of combat talk about the aggression to Poland without declaring war and the surprise effect of blitzkrieg (flash war). "Instead of this cynical and barbarian aggression, the calm and determined French react with patria appeal", the locution says with regard to the picture of men and women reading the call for mobilization. On the streets, children are sent to the countryside: "all was foreseen for your welfare and safety." Nurses put children inside trains by seeing their mothers' sad eyes. "Those who can, leave the cities". There is a portrayal of cars on the roads, crowded train stations, and urgency emphasized by music. "Poland's ambassador in France leaves flowers on the monument for the unknown soldier". "Foreign friends of France come to offer their support and aid". "A total of four thousand will enroll in the Foreign Legion". Other pieces of news are about measures as replacement of men mobilized by women and aged people, ensuring the normality of routine life. Scenes are usually framed in long and medium shots. They are short and pass quickly. On the other hand, oppositely, locution is paused and overjoyed, followed by an emotional musical background.

A new segment opens with the picture: "WHAT HE SAID" and the several acts of Hitler, and his promises are denied with "WHAT HE DID". As a response to this, images show fusions between French symbols like the Arc de Triomphe or the Notre-Dame Cathedral and men marching together with a martial sound, newspaper pages with headlines, and of voice that talks about the collaboration with England and its First Minister, who declares fighting against injustice and oppression. As seen, these are images and speeches produced inside a studio with stock shots (a pile of recorded scenes). The only original information is the audio of Chamberlain's statement. On the other hand, Daladier's speech, the French Council president, is shown through the picture of men and women in bars listening to the radio - file pictures. From it, one can hear a small extract. There is no rhetorical use of this official speech, which was not even recorded. In the end, differently, the French national anthem lines are recited in a paused manner - "Allons enfants de la patrie, le jour de gloire est arrivé" — over images of soldiers, military airplanes in action, cannons, ships, sailors, and marching soldiers. When the movie gets into the part "Aux armes citoyens", it shows soldiers from the colonies until it comes to an end with scenes of the army marching, which are taken in low-angle shot, ${ }^{48}$ with the anthem being emotionally sung over heroism icons of the monument of Arc de Triomphe in fp. “THE END”.

${ }^{48} \mathrm{It}$ refers to the framing that the camera does below the eyes level and headed above. It is the "low camera" and its main effect is to widen the framed object. 
Wenger spoke:

Until September 4th, the Reich kept the negotiations, with the only aim of making his population believe that the allies were those responsible for war declaration. But Hitler had been wanting to destroy Poland since April, when he ordered preparation of war against Poland on September 1st. In the meantime, in Danzig, ${ }^{49}$ the SS [elite body of the Nazi party] began simulated exercises against German facilities as if they were Polish, creating a pretext for combats.

In the newspaper UFA (Universum Film-Aktien Gesellschaff) — the German cinematographic studio - , there were scenes of the consequences of these attacks: burial of Germans and women crying with children on their laps. "Terrified" German populations, according to the voice speaking over. The camera registers in close up a sad kid, a sobering woman, and an old man. The pictures are individualized, paused - the camera withholds, they do not go fast in the editing film. A fire, an off voice explains that is was a Polish act. Dramatic song plays. The city is a wreck, the voice talks in a teasing tone: "Completely in peace, the Polish destroyed homes." There is even a statement in the voice of a man who lost his house and family. The voice says: "you can see", then the camera goes through the destroyed house.

\section{Since the 1960s, due to local circumstances of larger access to university, there was a demand for historical productions}

The sound of the statement in newsreels was not usual. It was unlikely to be obtained outside a studio because it demanded heavy equipment. Doing it, even as a simulation dubbed in a studio, demonstrates a worry with realism of the pictures and at the same time it creates an alleged true in loco statement.

English diplomats are in the picture, walking through London and the voice comment is about its fakeness, the breaking of promises, and 20-year-old lies. "That is why the September 1st attack re-established peace and rights of German citizens in Danzig". We see pictures of tanks, conflicts that were always attributed to the Polish, the sound of shots, fires, screams, voices, which were sounds that were added. "While in Berlin, Hitler was vainly waiting for a Polish negotiator with a peace offer". In the picture, Hitler arrives in Reichstag. In Danzig, there are pictures in long shot of soldiers celebrating. The troops enter the city and are greeted by the crowd. Screams of joy and words of order are heard (edited, superposed to the in loco captured pictures). Nazi flags in the windows declare the occupation and form the scenario for recording the triumphal parade and the party of the occupation of the Polish city by the German army.

${ }^{49}$ Danzig is the current Polish Gdansk. 
A new segment shows the safety measures in Germany, similar to what was seen in the French newsreel. Here, however, image focuses only on the weaponry: anti-air defense and soldiers handling devices on the terrace of a building from which the city is being taken, dominated by several angles. "Our weaponry industry is constantly producing". In the factory general plan, machinegun tubes and rifles are seen. The camera does a long lateral travelling, ${ }^{50}$ showing all manufactured equipment. Then, a derrick in movement dominates the factory from above, exhibiting the several lines of military cars that are still under construction. They are all in straight lines, organized and looking triumphal like in the parade recorded by Leni Riefenstahl in Triumph of the will (1935). The image of the factory in long shot, crossed by other horizontal travelling, in which several eager technicians and employees are seen with their aprons on, working under the supervision of military officers wearing their uniforms, closes this segment of the movie. Thus, it creates, in the shape of a mounting line orchestrated rhythmically, the idea of competent technique organization, and of order and preparation. The officers that go through the rows, however, introduce in the iconography and in the gestural what would be a factory supervisor of the war and oppressive authority that emanates from the Nazi war machine on all the other instances.

Meanwhile, in the Polish battlefield, troops break the border mark using tanks, and soldiers on horses and motorcycles. In a picture taken inside a house, we can see those living there on their backs, greeting the passage of the German army. The film penetrates inside a "free" happy house (we do not see their faces!). There is an enthusiastic song playing. From the peak of the mountain, a German soldier protects the arrival of troops in the plain. Combats. Western scene.

In a new scene, pictures of the air force appear: an aviator walks amid a foggy sky, as he had left the fog, as Riefenstahl had already done with Hitler in the beginning of its 1934 movie. In the background, there is a succession of lined airplanes. In such a scenario, the voice evokes the destroyed Polish airplanes on the ground. In close up, we can see pilots getting ready for departure and they are framed in the same way during the flight. Later, plan of the airplanes is set, and below them there is a river. A pilot shoots. We heard gunshots. Another airplane throws bombs. The movie stays in these images for a long time for they are very beautiful. On the ground, there are scenes of bombing and the narration speaks about the discomfit Polish fortresses. There are images of the city and smoke of bombs falling. But they are subtle, far away. There are scenes of combat from the harbor where Danzig was taken from a German ship that bombed the city. "The Polish population retreated", and then we see people taken in American territory walking through a road with pictures of burned houses, destroyed bridges, wrecked trains, whose destruction is falsely attributed to the Polish. "The population thanks. Their days of horror have come to an end": we see a man pulling a street sign in Polish. German soldiers receive food from the population, who is not smiling.

${ }^{50}$ In the travelling, the camera moves in the space following an action. 
Through the development of this segment of records about the battlefield, a small action movie is made, evoking the format of war movies, which a genre that started to be developed before World War I. ${ }^{51}$ It is also where, between fights, romances, compliment to military organizations or criticism to stupidity of confronts, aviators were considered heroes, as modern gentlemen, and the recordings of action in air, the great spectacle as seen in Maudite soit la guerre, by the Belgian Alfred Machin (1914) or in the American versions in Wings, by William Wellman (1927), among others, are seen..$^{52}$ Many of these features are explored in such scenes that make use of shots from several angles and places like the hill, the plane, the harbor, and in the air, forming a lively portrait of combats and building their heroes.

As noticed, there is a very well planned and mounted coordinated thematic linking between the occurrences in the battlefield and those produced in the rearguard, as shown in the previous "documentary" about the factory, for example. If there is conflict, it was caused by the enemy. In the battlefield, there are no losses or people hurt, there are only losers and winners. In the rearguard, weaponry is prepared to continue the attacks, or even better, "the defense".

Franz Wenger's comment:

In the German pictures, there is no war, there is retaliation; Germany is defending itself from Polish attacks and provocations. Germany did not open combats. However, French pictures are opened with the word War. Were the French aware of the severity of this situation?

Yes, Ferro answers: "They and the English had declared war against Germany, but what calls the attention on Pathé pictures is the 'wide-open pacifism' as it was named, the pacific atmosphere despite the newspaper title". For Wenger, something similar was happening in Germany but there was no enthusiasm.

Ferro reports that in the German pictures of ceremonies organized with authorities, the images are full of joy, whereas in those that were not, like departures at the stations, there is no joy among the French. This hints at the preparation of recordings for these events and the audience's control on reactions while acting in the staging. Nevertheless, Ferro reminds, "Germans do not think they can be defeated - they had just dominated Poland —, while in France, the drama is that the French believe they would be defeated, which is a heavy burden".

Wenger says that it explains the optimistic tone of the Pathécurrent events. We have the impression that time of these current events is delayed if compared to public opinion. Yes, Ferro says, it does not speak of what is severe, like it avoided making the spectator enter drama, like if there was some kind of complicity between the public power that only talks about peace and the current events that do not show what is happening - a tragic fact! On the German side, completes Wenger, current events precede public opinion. They announce measures and provide time tone, the one to be followed to live, to fight against war.

51Pierre Sorlin, Cines europeos, sociedades europeas: 1939-1990, Barcelona, Paidós, 1996, p. 31.

${ }^{52}$ About the gender, check J. David Slocum, Hollywood and War: the film reader, Oxford, Routledge, 2006. 
Another point discussed in both newsreels, Ferro remembers, is the Treaty of Versailles, "violated" for the French and "betrayed" for the German. "We talked about the same thing in a reversed manner". Laughs. Ferro:

Well, this treaty was unbelievable. It was based on the right of self-determination by the peoples, which is a nice principle, but abstract, of which the French did not reflect upon. They did not reflect upon the right of their colonial peoples, for example. And this would be relevant to all peoples, except for the Germans, which gave a great responsibility to the winners. It was a big injustice for the Germans and there was a very big difference between words and the facts that it left to furious Germans.

Wenger observes: “The Germans did not believe they had lost the war, but had to sign the Treaty of Versailles, because the army hid the defeat and the Nazi used it as if it was of the allies' bad will".

The broadcast leads to the conjugation of looks on the same object seen from different points of view, not only to the exchange of impressions and historical reviews from the different angles of the battlefield, but also to the "compassion by the other" of what Hanna Arendt says. Thus, it follows toward a convergence of interpretations that is certainly needed the conciliation of the present time — year of 1989 — of the program.

\section{Broadcast 3: 09/14/1939}

Ferro's introduction about the Polish defeat: "The Polish, who seemed strong, were soon beaten by the surprise war of the German, but they were heroic".

In Pathé images, French, English, and Belgian continued their mobilization for the war. Foreigners presented to fight for France, among them were the Czech who, in the row, were pushed by the French guards. Fait divers: elegance of the French woman with a purse using a gas mask! Among the news about Poland: "Paris finds its serenity again". People in the market are buying fruits.

Franz Wenger explains the reasons of the quick German advance, because the blitzkrieg destroys the Polish aviation and the communication pathways so it does not make the Polish attack viable. With the German forces, the anti-Polish and antiSemite propagandas advance. He makes remarks about the images of Bromberg's Night, a Polish attack on the German population that resulted in 5,000 deaths. In the newsreel, it is mentioned " 50,000 people murdered by the Polish", which served as a justification for army attacks on the Polish population, as seen in images. In the newsreel, the arrested Polish will have the "fair punishment". The destruction of bridges made by the German is attributed to them. However, "our military genius re-established in record time to continue the advance". Epic song.

In the picture, a series of old bearded men with mantle and crutches are seen: these are the Jews. According to the locution, "the Polish Jews are guilt of several provocations and incitation to the murder of Germans. Among them, dealers and criminals who had been infiltrating Germany since 1918". A slow lateral travelling frames the mesmerized old men, looking to the camera. The view of fragile, weak, and dirty men does not correspond to the threatening speech of the locution, 
even though this filmed character corresponds to the iconography that is widely explored in charges and placards, and that will be used in "documentaries" like The Eternal Jew (Der ewige Jude), by Fritz Hippler, filmed in 1940 in the occupied Poland. A place where these creatures are attributed the conspiracy by a malefic worldwide domination, thus it justifies the extermination that would start happening in that territory. "Currently, the siblings of these East Jews are in France and in England, where they cry out for the Germans' elimination". Travelling is over. Music is in an urgent tone. Field of Polish prisoners are dirty, tattered, ugly, "accused of piercing the eyes of German soldiers, a fact that is denied by the English". Wenger had already prevented the spectator about the lies in the pictures. Hitler, in the battlefield, examines maps of the army's advance together with officers. He walks among women and children. The sound is of a bawling crowd, like in the great Nazi spectacles from before the war.

\section{In the text "Criticism about the cinematographic current events, Parallel History," Ferro analyses these and other issues involving the work with filmic files}

Then, there is a new scene where Polish soldiers are going toward the camera and mention being happy for not fighting another lost cause that benefits England. They act for the movie. Once again, the witness voice is invoked for adding more "truth" to the filming. They have no shoes and are using torn socks. They are accepting cigarettes from German soldiers, complying for the camera with the humiliating role of sub-race that the Nazi attributed to the Polish. They get bread and soup in close up.

The German occupation in the city is a party. The tanks go through the streets that are already full of flags and the population is moving in their direction, waving happily. They are full of movement and rhythm scenes. The open military cars enter on the street in a straight line, taken in a slight low-angle shot, which emphasizes soldiers in their interior being hailed by women, children, and old people. These rhythmically approach the vehicles, coursing horizontally in fun groups on the streets - the construction evokes scenes of a musical -, until converging to where the militaries are and there forming a happy pillar that salutes the advance of tanks through the city. Goebbels, as noticed, was an excellent movie director and choreographer and had accompanied the Führer in his cinematographic sessions before war, when more than five movies were seen per night, among them many American productions. ${ }^{53}$ The locution reports that the German population is finally happy after 20 years of Polish interference over the city. The newsreel ends with a happy crowd, a column of soldiers, and the sound of a German anthem.

${ }^{53}$ According to Hitler, in Hitler, um filme da Alemanha, de Hans Jurgen Syberberg, 1977. 
Ferro's commentary:

In the German newspaper, there are war, defeat and victims. From the French side, we are in the absurd, in the ridiculous. A parody of 1914 war, but not the Poland drama, which does not appear, unless if it is a mass. France is asking for everybody's help.

He comments the Czech recruitment, who, in the picture, are being aggressively pushed by the French cops.

"Actually," Ferro says, "this [the gesture] expresses the comprehension that French people do not have reasons to enter the war, but they will have to do it because of the foreigners. It is a premonitory image of what the Armistice and Vichy will be". This is one of the many reflections from the historian, who, in a subtle remark of the images, finds this kind of evidence, whose not foreseen or desired meaning, opposite to locution, overflows from the image and allows new interpretations. What was called in the 1970s as a "lapse", now it appears as "information energy" of images that the historian must "tame".

For Wenger, in the UFA images, the four main themes of the German propaganda during war are already enrolled:

Germany is strong and will win; Hitler is the supreme commander and thanks to him, soldiers bring victory; the German army occupies, however it is a liberator: in Poland, there are only criminals, Jews or German: the anti-Semitism. These themes will be developed in newsreels from a foreseen script established by Goebbels.

\section{Conclusion}

In each show, the amount of information in the file materials and comments is huge and, in many ways, new by the superposition of newsreels and punctuations that are being composed in front of the spectator about the diversified ways of enunciation, of the emphasis given to the subjects and characters, besides new interpretations and information that the discussions and collisions between history and memory evoke. They have also evoked infatuated and contradictory reactions from the spectators that fairly criticized the show format for bringing back these images: "Your work is ignoble, you reproduce the Nazi propaganda and how it is stronger than you [author's emphasis], you make people become Nazi!" ${ }^{55}$ Such reaction not only expresses the spectators' attraction to the German propaganda, but also the supposed historian's weakness before the force of the images and conflicts between memory and history.

I have chosen to bring three consecutive programs from 1939 so that one can realize how the series worked during events in its succession, repetition, and reiteration. It allowed rescuing and living the own time of

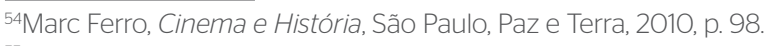

55/bidem, p. 102 
the occurrences and how they were manipulated and rebuilt by newsreels. In each week, experts went together, followed by the audience of the two countries, taking part in this history that was about to be rewritten, at the same time when the European history was also being completely changed. This dialog was part of it.

As seen, and reported by Ferro, the French newsreel - produced by a private company, Pathé - is linked to the occurrences and it also works with a solid repertoire that refers to World War I. Also, if it announces something, it is even by omission: the catastrophe that the weaponry declared. Its images are disordered, without control, and previous preparation. The French newsreel does not produce its events, and the French government not even had thought about its role of social regimentation. However, in the German, the documentary use that already foreseen and prepared war was strictly planned, as seen by the construction and manipulation of accomplishments, which has been clear since the beginning until the end. In addition, Goebbels' orientation about its elaboration, as driven by Franz Wenger, is perceptible, as I expect to have made clear in some punctuations about the staging forms, themes, how to approach them, and their linking through editing, use of resources like sound and voice of witnesses.

Historians are more focused on the historical content of the pictures, and Ferro, mainly, through comparison, finds new evidence about the war unfolding. It is basically his method of work. The final discussion is denser and may leave the exclusive scope of what is suggested by pictures, raising questions that are implied to the narrative enrolled there.

Punctuations or contexts do not take the spectator by the hand. There is a supposed audience knowledge, which is respected. They are not seen as ignorants that need to be guided and conducted. It is not necessary to didactically indicate - "take a look at this, take a look at that" — and, thus, meaning is closed. It is clear that there has been a pre-production with the materials that came before every broadcast, foreseeing its good development, rhythm, dialogue with the audience, and so on.

The show goes in the opposite direction from the intense production of movies concerning historical reconstitution, TV shows, or docu-fictions about World War II. These have been very common in Europe and mainly in France for the past 20 years, where the interest and duty to the memory of the Holocaust or discomfort with the Occupation have justified repeated productions, under the affirmation that the new generations must be advised against the repetition of these events. ${ }^{56}$ These commercial productions that, most of the times, happen to give more bearable meaning to occurrences of hard acceptance, have been ruled in their staging, "by the unification of the written forms of history in a hyper visibility aesthetics, immersion in the image and sound effects, pulverization

\footnotetext{
${ }^{56}$ The TV show Un village français about the Occupation and Resistance, broadcast in Brazil by TV5 Monde, is a good example of this kind of production. Available at YouTube and for download from: <https://www. youtube.com/results?search_query=Un+village+français++>. Accessed on: September 25, 2014.
} 
of duration and leveling of temporality". ${ }^{57}$ However, Histoire Parallèle chose to investigate newsreels as epoch documents. Instead of using these images as a raw material for a media production, it restituted spectators with the document, full or a little edited, and by doing so, the serial practice of waiting for pictures once a week on the TV screen liked used to happen at movie theaters in 1939.

On the other side, this points out to the treatment given by the historian to collisions between memory and history at that time. If we consider these movies, we are referring to them as a construction of a "prosthetics" memory, as Foucault in his remarks about the media previously presented. In the analyzed broadcasts, on the contrary, it has been settled a way that the historians may control the memorial flow through analyses that are more distant from the newsreels.

Finally, Histoire Parallèle provides a very good definition of the broadcast character: transformation of the file to a reflection subject (the meaning of the images is re-visited and re-adjusted). Through it, historians consecrate in this moment a meaning to a new Europe: the dialogue instead of a conflict. A new reading of the pictures is different from the original meaning: it is about understanding the other instead of beating it. The newsreel, which was originally broadcast only to the audience of each country, gets a new dimension with the bi-national television: spectators must simultaneously receive the images produced by their own governments and by the enemy, confront them, enter into discord, find the past meaning, and try to build a new meaning for their relations.

Histoire Parallèle is also defined by the historiographical work of Marc Ferro with History and images, but not only by that. He was one of the first historians to use Cinema in the same way and the same statute that was given to other sources, he used exposure and discussion of multiplicity and counter-position of sources and versions that crossed their paths cover and institute their privileged form of historical rescue and understanding. He exposed the tensions and collisions that mark the construction of history and contemporaneous power that happens without truce over it in the medias, as it was possible to follow in the program that he commanded. These three dialogs from 1989, which would be repeated for more 12 years, demonstrate until which point the historiographical new introduced by Marc Ferro remains recent, despite the evolution that studies about the relation between Cinema and History have been known since the 1970s.

57Sylvie Lindeperg, La voie des images, Paris, Verdier, 2013, p. 7. 